\title{
Biobutanol as a Potential Sustainable Biofuel - Assessment of Lignocellulosic and Waste-based Feedstocks
}

\author{
Johanna Niemistö ${ }^{* 1}$, Paula Saavalainen ${ }^{1}$, Eva Pongrácz ${ }^{2}$, Riitta L. Keiski ${ }^{1}$ \\ ${ }^{1}$ Department of Process and Environmental Engineering, \\ P.O. Box 4300, FI-90014 University of Oulu, Finland \\ e-mail: johanna.niemisto@oulu.fi, paula.saavalainen@oulu.fi, riitta.keiski@oulu.fi \\ ${ }^{2}$ Thule Institute, NorTech Oulu, P.O. Box 7300, FI-90014 University of Oulu, Finland \\ e-mail:eva.pongracz@oulu.fi
}

Cite as: Niemistö, J., Saavalainen, P., Pongrácz, E., Keiski, R.L, Biobutanol as a Potential Sustainable Biofuel Assessment of Lignocellulosic and Waste-based Feedstocks, J. sustain. dev. energy water environ. syst., 1(2), pp 58-77, 2013, DOI: http://dx.doi.org/10.13044/j.sdewes.2013.01.0005

\begin{abstract}
This paper introduces the production process of an alternative transportation biofuel, biobutanol. European legislation concerning biofuels and their sustainability criteria are also briefly described. The need to develop methods to ensure more sustainable and efficient biofuel production processes is recommended. In addition, the assessment method to evaluate the sustainability of biofuels is considered and sustainability assessment of selected feedstocks for biobutanol production is performed. The benefits and potential of using lignocellulosic and waste materials as feedstocks in the biobutanol production process are also discussed. Sustainability assessment in this paper includes cultivation, harvest/collection and upstream processing (pretreatment) of feedstocks, comparing four main biomass sources: food crops, non-food crops, food industry by-product and wood-based biomass. It can be concluded that the highest sustainable potential in Finland is when biobutanol production is integrated into pulp \& paper mills.
\end{abstract}

\section{KEYWORDS}

Biofuels, Biobutanol, Lignocellulosics, Waste, Biomass, Sustainability assessment, Renewable Energy Directive (RED)

\section{INTRODUCTION}

Governmental policies have been the main promoters of biofuels during the last decade. For example, the European Union has settled targets for biofuel and energy usage in the member countries. Promotion of renewable energy was started with the Directive 2001/77/EC and continued with the biofuel sector by the Directive 2003/30/EC. Later on, the Renewable Energy Directive (RED) 2009/28/EC [1] was introduced, including the aim of $10 \%$ biofuels share in transport sector by 2020 . The use of biofuels has a target of minimum reduction of 35\% (increasing to $50 \%$ by 2017 and $60 \%$ by 2018 for new installations for biofuel production) in GHG emissions compared to fossil fuels. In addition to EU, also many other countries have their own targets and legislation for biofuels [2].

Bioethanol and biodiesel are now the most used biofuels in the transportation sector, but also new alternatives such as biobutanol are needed to fulfill the demands. Moreover, it is important that biofuels are produced in as sustainable a way as possible. This article focuses on biobutanol as a potential renewable-based transportation fuel. In particular, production based on non-food feedstocks such as lignocellulosic materials and wastes/by-products is

\footnotetext{
${ }^{*}$ Corresponding author.
} 
considered and sustainability assessment is performed to evaluate different feedstocks. The hypothesis is that lignocellulosic and waste-based biobutanol is a sustainable transportation fuel. Finally, the sustainability of four different biobutanol feedstock materials is assessed, and the challenges associated with the evaluation of sustainability in biobutanol production are addressed.

\section{BIOBUTANOL -An alternative transportation fuel}

Butanol $\left(\mathrm{C}_{4} \mathrm{H}_{9} \mathrm{OH}\right)$ is an intermediate in the production of butyl acrylates, the ingredient of coatings and adhesives, as well as glycol ethers and butyl acetates [3]. Butanol is also commonly used as a solvent in the production of antibiotics, hormones and vitamins [4]. Production is typically done by the chemical Oxo process, where propylene is reacting with carbon monoxide and hydrogen in the presence of a catalyst, followed by the hydrogenation of formed aldehydes to a mixture of iso- and n-butanols [3]. Biobutanol can also be produced from biomass materials biochemically via a fermentation process. The fermentation process for biobutanol production was already introduced in the 1910s [5] and used in an industrial scale until many plants were closed during the 1960s due to the inability to compete with chemical production processes [6]. During the last decade, interest in the process has arisen again due to the considerable potential of biobutanol as a transportation fuel. While ethanol is a commonly used fuel additive, the properties of butanol are comparable to gasoline and in many ways superior to ethanol (Table 1).

Table 1. Fuel properties of biobutanol and advances compared to ethanol [7-9]

\begin{tabular}{|c|c|}
\hline Property & Advances compared to ethanol \\
\hline Blending ability & $\begin{array}{l}\text { Can be blended with gasoline or diesel fuel in higher } \\
\text { concentrations without the need of vehicle retrofitting. } \\
\text { With higher concentrations also the share of renewable } \\
\text { components is increased in the final fuel mixture. }\end{array}$ \\
\hline $\begin{array}{l}\text { Energy content, octane } \\
\text { values and air-to-fuel ratio }\end{array}$ & $\begin{array}{l}\text { Values are closer to gasoline than ethanol: better fuel } \\
\text { economy (kilometers per liter) than with ethanol. }\end{array}$ \\
\hline Less evaporative & $\begin{array}{l}\text { Safer to use and handle than ethanol and generates lower } \\
\text { amounts of volatile organic compound (VOC) emissions. }\end{array}$ \\
\hline $\begin{array}{l}\text { Lower water } \\
\text { solubility }\end{array}$ & $\begin{array}{l}\text { Compared to ethanol, decreased tendency of corrosion in } \\
\text { pipelines and fuel tanks, and if spills or leaks happen, the } \\
\text { tendency for spreading in the groundwater is reduced. }\end{array}$ \\
\hline $\begin{array}{l}\text { Lower vapor } \\
\text { pressure }\end{array}$ & $\begin{array}{l}\text { Compared to ethanol, decreased tendency of corrosion in } \\
\text { pipelines and fuel tanks. }\end{array}$ \\
\hline Biodegradability & $\begin{array}{l}\text { Butanol is more biodegradable than ethanol and will } \\
\text { biodegrade in the environment under aerobic conditions. }\end{array}$ \\
\hline
\end{tabular}

Several reviews on biobutanol production have been published recently [6, 10-12] and there is a number of active biobutanol production plants in China [13]. In addition, companies such as DuPont, British Petroleum, Cobalt Technologies and Gevo Inc. are investigating biobutanol production and aiming to initiate industrial scale production. In terms of sustainability, the key concern is the feedstock of biobutanol production. The selection of feedstock will also impact on the production process. The assessment presented in this paper considers the biochemical production route of butanol and six different categories of feedstock sources. 


\section{Biochemical production process of biobutanol}

The main steps with alternative processing techniques of the biobutanol production process are illustrated in Fig. 1. As the cost of raw material has a significant influence on price [14], the main interest has recently been in low-cost substrates such as agricultural residues or industrial by-products and waste materials. Upstream processing before the fermentation includes the pretreatment of feedstock biomass, hydrolysis, and in some cases detoxification of inhibitors formed during the pretreatment. The fermentation step is commonly called as Acetone-Butanol-Ethanol (ABE) fermentation, based on the main products. This anaerobic fermentation consists of two stages: first the acidogenic phase where Clostridial bacteria produce acetic and butyric acids, carbon dioxide $\left(\mathrm{CO}_{2}\right)$ and hydrogen $\left(\mathrm{H}_{2}\right)$ from sugars, followed by the solventogenic phase where acids are converted into acetone, butanol and ethanol, typically in the ratio of 3:6:1. After the fermentation, final products are recovered and purified in downstream processing [15]. Adsorption, gas stripping, liquid-liquid extraction, pervaporation, perstraction and reverse osmosis are the most used separation methods integrated with the ABE fermentation [16].

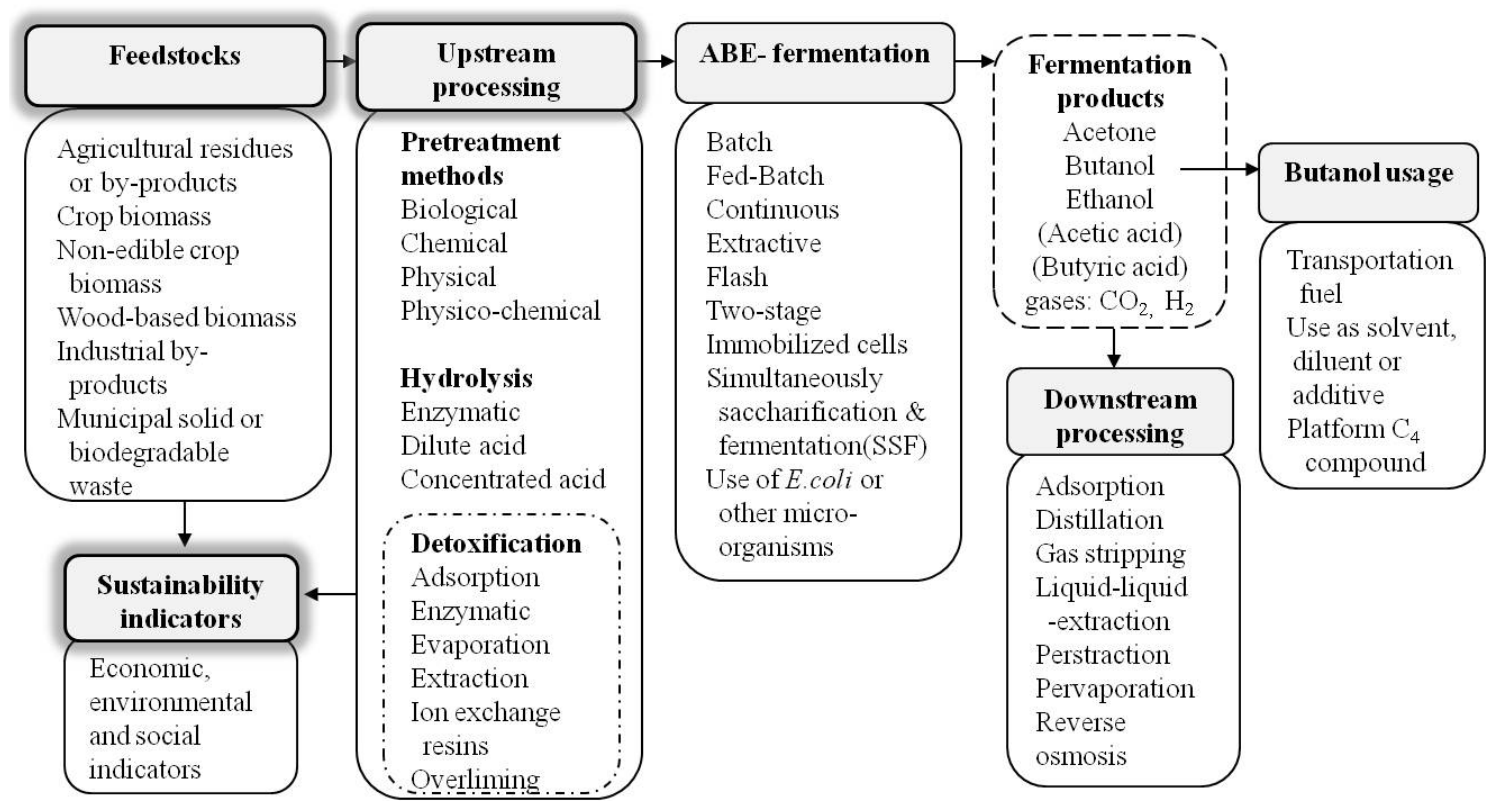

Figure 1. Steps in the biobutanol production process (modified from [10])

The main shortcoming of this biochemical production pathway is the low yield of the fermentation process, caused mainly by butanol inhibiting the growth and metabolism of Clostridia. Thus, there is a need to find improvements for the fermentation process. Research has been done e.g. by modifying the bacterium strains to stand out inhibitors better, by enhanced fermentation techniques, and by combining the downstream part into the fermentation step and removing butanol continuously from the system [11]. Novel feedstocks and optimized production processes for utilization of the raw materials are also essential development areas for more sustainable and efficient production of butanol. In this paper, the focus is especially on the selection of different feedstocks and their influence on the sustainability for the process.

\section{Feedstocks for biobutanol production}

Biobutanol can be produced biochemically from a range of feedstocks. When selecting the raw material for an industrial scale process, plentiful supply, low price, reasonable 
transportation costs and the ease of feedstock bioconversion should be taken into consideration. Molasses, potato, corn and other starch materials as well as cassava have been the principal raw materials used in industrial scale production of biobutanol [6]. Despite the fact that fossil fuel based chemical production process of butanol took over the fermentation process, research and development of biochemical process continued during the 1980s and 1990s, and new raw materials were tested. Interest in the process arose again in the beginning of the 21st century, focusing mainly on non-food residues and wastes. Use of by-products and waste materials is desirable also in terms of resource efficiency and waste minimization. Table 2 illustrates the advantages of different biobutanol feedstocks.

Table 2. Feedstocks used for biobutanol fermentation process

\begin{tabular}{|c|c|c|c|c|}
\hline $\begin{array}{l}\begin{array}{l}\text { Feedstock } \\
\text { source }\end{array} \\
\end{array}$ & Examples & Advantages & Disadvantages & Ref. \\
\hline $\begin{array}{l}\text { Agricultural } \\
\text { residues or by- } \\
\text { products }\end{array}$ & $\begin{array}{l}\text { Bagasse, } \\
\text { corn } \\
\text { stover/fiber/cobs, } \\
\text { straws (e.g. from } \\
\text { barley, rice or wheat) }\end{array}$ & $\begin{array}{l}\text { Easier upstream } \\
\text { processing to } \\
\text { fermentable sugars }\end{array}$ & $\begin{array}{l}\text { Seasonal availability, } \\
\text { Variations in cultivation } \\
\text { yield and quality, } \\
\text { Land-use change, } \\
\text { Transport costs (low } \\
\text { density) }\end{array}$ & $\begin{array}{l}{[17-} \\
25]\end{array}$ \\
\hline Crop biomass & $\begin{array}{l}\text { Cassava, } \\
\text { corn }\end{array}$ & $\begin{array}{l}\text { Easier upstream } \\
\text { processing to } \\
\text { fermentable sugars }\end{array}$ & $\begin{array}{l}\text { Edible, } \\
\text { Seasonal availability, } \\
\text { Variations in yield } \\
\text { and quality, } \\
\text { Land-use change, } \\
\text { Water need for irrigation }\end{array}$ & $\begin{array}{l}{[26-} \\
28]\end{array}$ \\
\hline $\begin{array}{l}\text { Non-food crop } \\
\text { biomass }\end{array}$ & $\begin{array}{l}\text { Switchgrass, } \\
\text { Jerusalem artichoke }\end{array}$ & $\begin{array}{l}\text { Does not compete } \\
\text { with food use }\end{array}$ & $\begin{array}{l}\text { Land-use change } \\
\text { possible if fertile land is } \\
\text { used, } \\
\text { Potential water need }\end{array}$ & $\begin{array}{l}{[29,} \\
30]\end{array}$ \\
\hline $\begin{array}{l}\text { Wood-based } \\
\text { biomass }\end{array}$ & $\begin{array}{l}\text { Wood hydrolysates } \\
\text { (e.g. from aspen, } \\
\text { pine, beech or } \\
\text { hemlock) }\end{array}$ & $\begin{array}{l}\text { Non-food biomass, } \\
\text { Good availability, } \\
\text { Lower transport } \\
\text { costs }\end{array}$ & $\begin{array}{l}\text { More difficult upstream } \\
\text { processing, } \\
\text { Indirect land-use change } \\
\text { possible }\end{array}$ & $\begin{array}{l}{[18,} \\
31- \\
34]\end{array}$ \\
\hline $\begin{array}{l}\text { Industrial } \\
\text { by-products }\end{array}$ & $\begin{array}{l}\text { Apple pomace, cheese } \\
\text { whey, Distillers Dry } \\
\text { Grain Solids (DDGS), } \\
\text { potato waste, brans } \\
\text { (e.g. from rice or } \\
\text { wheat), soy molasses, } \\
\text { waste sulfite liquor }\end{array}$ & $\begin{array}{l}\text { Better social } \\
\text { acceptance by means } \\
\text { of resource use } \\
\text { efficiency and waste } \\
\text { minimization } \\
\text { No land-use change }\end{array}$ & $\begin{array}{l}\text { Availability and } \\
\text { quality of the raw } \\
\text { material may vary, } \\
\text { Additional processing } \\
\text { may be needed to } \\
\text { separate the feedstock } \\
\text { from the main product }\end{array}$ & $\begin{array}{l}{[35-} \\
50]\end{array}$ \\
\hline $\begin{array}{l}\text { Biodegradable } \\
\text { municipal } \\
\text { waste }\end{array}$ & $\begin{array}{l}\text { Food and garden } \\
\text { waste, starch-based } \\
\text { packing peanuts, } \\
\text { sludge from } \\
\text { wastewater } \\
\text { treatment }\end{array}$ & $\begin{array}{l}\text { Better social } \\
\text { acceptance } \\
\text { contributes to } \\
\text { resource efficiency } \\
\text { and waste } \\
\text { minimization, } \\
\text { No land-use change }\end{array}$ & $\begin{array}{l}\text { (Seasonal) and } \\
\text { qualitative variation }\end{array}$ & $\begin{array}{l}{[51-} \\
55]\end{array}$ \\
\hline
\end{tabular}




\section{LEGISLATIVE CONSTRAINTS OF BIOFUEL SUSTAINABILITY IN THE EUROPEAN UNION}

The Fuel Quality Directive (2009/30/EC) of the European Union (EU) sets minimum limits for the quality of transportation biofuels while the Renewable Energy Directive (RED) (2009/28/EC) includes three relevant articles in respect to sustainability: Sustainability criteria for biofuels and bioliquids (Article 17), Verification and compliance with the sustainability criteria (Article 18) and Calculations of the greenhouse gas impact of biofuels and bioliquids (Article 19). Articles are described briefly below [1, 56]:

Article 17 sets sustainability criteria (both qualitative and quantitative) for all biofuels produced either inside or outside the European Union. These include for example feedstocks and indirect land use: Areas with high stocks of carbon, highly biodiverse grassland, peatlands, primary forests and protected areas are not allowed to be used. The European Commission (EC) should report to the European Parliament and the Council every second year about the measures taken to follow the sustainability criteria and the protection of soil, water and air when producing biofuels in the Member States or in third countries. There are no compulsory criteria for economic and social sustainability for Member States, but the EC should also report the impact of the biofuel policy on the availability of foodstuff at affordable prices, and respect of land-use rights and wider development issues. This concerns in particular the situation with people living in developing countries. Information of ratification and implementation of given Conventions of the International Labour Organisation within the main producer countries should also be included in the report.

Based on Article 18, economic operators (e.g. farmers, biofuel producers, distributors and vendors) of each Member State need to show that given sustainability criteria are followed. GHG impact calculation is done by using a mass balance system allowing mixing of biofuels or raw materials with varying sustainability characteristics. Operators are required also to arrange sufficient standards for independent auditing of the information. If raw materials or biofuels are imported, bilateral or multilateral agreements including guarantee of the compliance with the sustainability criteria also within the third world countries should be sought. The EC can demand a producer to give a demonstration that biofuel produced from raw materials cultivated in non-EU countries comply with sustainability criteria.

Article 19 includes the methodology for calculations of GHG emissions and gives default values for 22 biofuel production pathways. These values are valid only when cultivation of raw materials does not cause change in land use. The cultivation should also take place outside the EU or in the EU area which is classified as level 2 or more disaggregated level in the nomenclature of territorial units for statistics (NUTS). In these areas, the typical GHG emissions from cultivation are expected to be equal or lower than emissions reported in the list of "Disaggregated default values for cultivation" in part D of the Annex V.

\section{Biofuel standards}

The EC is not demanding but encouraging industry, governments and non-governmental organizations (NGOs) to set up voluntary certification schemes for biofuels. The Certification guarantees that biofuels produced under the certified label are sustainable and production is done according to criteria given in RED. [57]

At present, the following European Sustainability criteria for the production of biofuels and bioliquids for energy applications - Principles, criteria, indicators and verifiers - EN 16214 standards have already been approved and published; Part 1: Terminology, Part 3: Biodiversity and environmental aspects related to nature protection purposes and Part 4: 
Calculation methods of the greenhouse gas emission balance using a life cycle analysis approach. Further, approval of Technical report prCEN/TR 16214-5, Part 5: Guidance to the conformity assessment and the use of the chain of custody and mass balance will be voted on summer 2013. FprEN 16214-2 Standard proposal Part 2: Conformity assessment including chain of custody and mass balance is not yet approved and will go to another voting. [58]

There is also an international standard draft ISO/CD 13065 'Sustainability criteria for bioenergy' under preparation, but most probably it will be available only after few years [59]. So at the moment, all standards made by CEN Technical Committee (TC) 383: Sustainability produced biomass for energy applications are not yet approved. It seems also that at least the standard parts approved at the moment include neither GHG emission and fossil fuel balances, biodiversity, environmental, economic and social aspects nor indirect effects.

\section{EVALUATION OF BIOBUTANOL PRODUCTION PROCESSES}

\section{Evaluation of feedstocks and unit processes}

There are only a few assessments of biobutanol production available in the literature and most of them evaluate only economic sustainability. In 1980, Lenz \& Morelra [60] found that high-quality molasses was an unattractive alternative at that time, whereas liquid whey waste material was found to have better economic potential. Gapes [61] concluded in 2000 that Acetone-Butanol fermentation may be economic when cheap, low-grade substrates are processed on a relatively small industrial scale. In contrast, when Pfromm et al. [62] compared the technical and economic aspects of fermentative biobutanol and bioethanol production processes using corn and switchgrass, they concluded the ABE process to be disadvantageous at the level of technology in 2010. The reason quoted was the low yield and productivity per time and volume of fermenter and the lower heating value per gram of processed biomass, as compared to bioethanol production by yeast fermentation. Recently, Kumar et al. [63] compared cellulosic (bagasse, barley straw, wheat straw, and switchgrass) and non-cellulosic (glucose, sugarcane, corn, and sago) feedstocks. Sago and glucose were too costly as feedstock biomass, while sugar cane and cellulosic materials were economically feasible with production costs of $0.59-0.75 \$ / \mathrm{kg}$ of butanol. Further, fermenter size, plant capacity and production yield were noticed as crucial design and process parameters. In 2004, Ramey \& Yang [64] reported production costs of 1.07 \$/gallon $(0.33 \$ / \mathrm{kg})$ for their process starting from corn and cost of $0.54 \$ /$ gallon $(0.17 \$ / \mathrm{kg})$ for whey permeate used as a feedstock. With the current butanol price in Europe, about $1.50 \$ / \mathrm{kg}$, the biochemical production can be feasible already in this stage of the art. As comparison, production costs for petroleum-based butanol are about $1.35 \$ /$ gallon $(0.44 \$ / \mathrm{kg})$ [65]. However, the process is using propylene as starting material and thereby production costs of the chemical process are very sensitive to the crude oil price.

Different recovery methods have been evaluated together with the economics of the butanol production process [16,66-70]. For instance, pervaporation (a membrane-based separation technique) may reduce production costs, especially if combined with the fermenter as a hybrid process [6,71,72]. Recently, conceptual designs of alternative process routes for biobutanol production from sugarcane molasses were done using Aspen Plus and Aspen Icarus modeling tools [73]. Different fermentation modes (batch or fed-batch), bacterium strains (Clostridium acetobutylicum ATCC824 or PCSIR-10, Clostridium beijerinckii BA101) and downstream processing techniques (steam stripping distillation, liquid-liquid extraction or gas stripping with $\mathrm{CO}_{2}$ ) were investigated. Fed-batch 
fermentation with gas stripping was evaluated to be the only viable design in present economic conditions in South Africa, but the technology is still unproven on the industrial scale.

\section{Production pathway analysis (GHG emissions)}

Natural Resources Canada has developed a model called GHGenius for the estimation of life cycle energy balances and emissions of the primary GHGs and of many other contaminants in connection with the production and use of existing and potential transportation fuels. Emissions can be predicted for the past, present and the future as far as 2050. This model was used for the analysis of the corn-to-butanol pathway [74]. Another calculation model, GREET (the Greenhouse Gases, Regulated Emissions and Energy Use in Transportation), was developed by Argonne National Laboratory. This well-to-wheels (WTW) analysis tool is based on the evaluation of different vehicle-fuel combinations on the basis of full fuel-cycle or vehicle-cycle. The model consists of Microsoft Excel multidimensional spreadsheets and calculates the consumption of energy, emissions of carbon dioxide $\left(\mathrm{CO}_{2}\right)$, methane $\left(\mathrm{CH}_{4}\right)$, nitrous oxide $\left(\mathrm{N}_{2} \mathrm{O}\right)$ and other pollutants, i.e. volatile organic compounds (VOCs), carbon monoxide (CO), nitrogen oxides $\left(\mathrm{NO}_{\mathrm{x}}\right)$, sulfur oxides $\left(\mathrm{SO}_{\mathrm{x}}\right)$ as well as particulate matter measuring 10 micrometers or less $\left(\mathrm{PM}_{10}\right)$ or 2.5 micrometers or less $\left(\mathrm{PM}_{2.5}\right)$ [75]. Using the GREET model and the Aspen Plus simulation tool, $\mathrm{Wu}$ et al. [76] estimated the potential life-cycle energy and emissions effects associated with the use of biobutanol. They concluded that vehicles fueled with biobutanol produced by the examined process could result in fossil energy savings of 39-56\%, and reduction of 32-48\% of GHG emissions compared to conventional gasoline.

Recently, Swana et al. [77] evaluated the net energy production and feedstock availability for transportation biofuels by life-cycle assessment. Studied feedstocks included switchgrass, hybrid poplar, corn stover and wheat straw, all assumed to be produced domestically for biofuel production in the US. They concluded that by sustainable harvest based on current yields in the US, these biomasses can be converted to 8.27 billion gallon (31.31 billion liters) of biobutanol vs. 10.31 billion gallons (39.03 billion liters) of bioethanol. Since butanol has a better energy density, the replaced amount of gasoline is higher: 7.55 vs. 6.97 billion gallons with ethanol. It is to be mentioned that, with 2010 consumption levels of 378 million gallons/day, this is sufficient for merely 20 days of automotive transport without efficiency measures to reduce the fuel consumption. Ultimately, it will be crucial to restrain present consumption levels.

Directives do not specify the standard conversion values or the input numbers used to obtain the default values for each economic operator's calculations. To harmonize the GHG calculation system for biofuel emissions, specialists from several EU countries have been united within the BioGrace project during 2010-2012 [78]. They listed all standard conversion values needed for GHG emission calculations and provided an Excel-based software for performing the calculations. Development and implementation of the software was done together with governmental policy makers, economic operators, auditors, advisors and certifiers. In addition, the Roundtable on Sustainable Biofuels (RSB) [79] is an international intent to bring together players from all fields for ensuring the sustainability of the production and processing of biofuels. This initiative has also developed a third-party certification system. 


\section{SUSTAINABILITY ASSESSMENT OF FEEDSTOCKS FOR BIOBUTANOL PRODUCTION}

Sustainable development is the cornerstone of environmental policy and a leading principle for resource management. Sustainability can be envisioned as an equilibrium state between economic success, social acceptance and environmental protection. [80] In industrial applications, sustainability is often summarised as the "triple bottom line" success covering the three components of sustainability - environmental responsibility, economic return (wealth creation), and social development [81]. However, there is no standard method for measuring the triple bottom line success, and it is especially difficult to assess processes in the early design phase to have the understanding of the full impact of design changes.

\section{Economic, environmental and social impacts of biofuel production}

In terms of economic impact, the price of feedstock and the costs of biofuel production are the most defining impacts. The cost of biofuel production can be calculated mainly based on the capital and operational costs of the process. According to Demirbas [82], operational costs (e.g. feedstock, chemicals, labor, maintenance, insurances, taxes) represent about one third of the total cost per liter of fuel, while the share of capital costs is about one-sixth of the total cost per liter. There may be great variations in the production costs of the chosen raw materials, process techniques, and the scale, capacity and location of the plant. In debates about the positive effects of renewable and bioenergy projects, the aspect of generating regional added value is discussed [83, 84]. Heck [83] suggests regional added value to be defined as "the sum of all additional values originating in a region in a given time period”. Further, "particularly social, ethical and environmental issues should be considered in addition to the purely monetary aspects such as cost reduction, increase of purchasing power, higher tax revenues, and retention and generation of jobs” [83].

Environmental impacts in relation to biofuel feedstocks include direct and indirect land-use changes (LUC and ILUC), water footprint and other natural distraction. LUC and ILUC can have significant impacts on greenhouse gas balances and eutrophication [85-87]. The risks of nutrients removal, soil erosion and water run-off, as well as loss of natural biota, habitats and wildlife also have to be considered [88]. The expected positive impacts by using biomass based raw materials are reduced need of fossil fuels, potential GHG savings and improved carbon economy [82]. In addition, the biofuel production process has direct environmental impacts in terms of energy consumption and waste generation. In our assessment, we have evaluated the different challenges which each feedstock presents in terms of energy and water consumption during its pre-processing as well as the amounts of wastes/by-products they entail. Special attention is given to the use of toxics in pre-processing, as it will also impact on the safety of employees.

Regarding social impacts, biofuels in general are credited with enhanced energy security due to reduced dependency on imported crude oil, as well as increased employment. In our assessment of different biomass feedstock, providing jobs and development of rural areas are considered as positive impacts, especially in the case of raw materials from the agricultural and forest sectors. A key element in comparing different feedstocks is competing demand of feedstock, especially in the case of food-based feedstocks. For this reason, the ethical considerations are also assessed. This will also impact on customer acceptance, which may be subjective and is a theme of actual social dialogue. Some of the feedstocks assessed are currently still under research as potential raw material of biobutanol production. In terms of wider societal impact, the innovation and knowledge potential 
research efforts also need to be considered. As well, education and training for new processes will positively impact on societal capital.

\section{MATERIALS \& METHODS}

\section{Assessment process for the selected feedstocks}

To understand the combined impacts of feedstock supply and the production process, all three aspects of sustainability should be taken into consideration simultaneously. Currently, there is no unified triple bottom line assessment method available. In addition, while economic and environmental impacts can be quantified, most social impact categories can only be described in qualitative terms. In order to provide comparable data, we used a methodology described in Saavalainen et al. [89] in the assessment. A numerical value between +2 and -2 was assigned to all impact categories, illustrating the level of influence; positive impact was valued by a positive amount up to +2 , depending on the potency of positive influence. For negative impacts the values were negative, with -2 for the most severe impact. In the case that the selected feedstock had no influence towards either direction, the value of 0 was assigned. This method allows for the comparison of all impact categories at the same time and visualizing with a spider diagram.

As a boundary condition for this sustainability study, it was assumed that the biobutanol is produced in a western European country, Finland if feasible. The assessment is limited to cultivation, harvest/collection and upstream processing (pretreatment) of feedstocks, excluding the rest of the process chain. Four main biomass sources were compared: food crops represented by corn, non-food crops illustrated by straw, food industry by-product with whey permeate as an example and sawdust as a representative of wood-based biomass. The assumptions for all four feedstocks used in the assessment are summarized in Table 3.

Table 3. Assumptions made for the feedstocks

\begin{tabular}{lc}
\hline Corn & Whey permeate \\
\hline - crop biomass & - food industry by-product \\
- is imported & - could be used as fodder or as raw material \\
- could be used as food & for nutrient additives/products \\
- starch/sugar (glucose) content $~ 71 \%$ & - sugar (lactose) content $\sim 50 \%$ \\
- in cultivation, lot of water as well as & - biobutanol production facility is integrated \\
fertilizers and pesticides are required & with a food industrial factory \\
- pretreatment is done by wet milling with & \\
sulphuric acid & \\
\hline Straw & Sawdust \\
\hline - non-edible crop biomass or agricultural & - wood based biomass \\
waste & - is an industrial by-product that would \\
- sugar (cellulose and hemicellulose) content & otherwise be used in energy production \\
$\sim 70 \%$ & - sugar (cellulose and hemicellulose) content \\
- contains also ashes and extractives which & $\sim 70 \%$ \\
make processing more complicated & - biobutanol production facility is integrated \\
& with a paper and pulp factory \\
& - steam from pulp and paper factory can be \\
\hline
\end{tabular}




\section{RESULTS OF THE SUSTAINABILITY ASSESSMENT}

The following indicators of the selected feedstock were assessed: Feedstock price, processing costs, and value added for economic impact; environmental impacts were evaluated for water consumption, toxic material usage, biodiversity and land use impacts, amount of wastes vs. by-products generated and energy consumption. For social impact assessment, the ethics of the feedstock use was evaluated based on competing demand; current customer acceptance and social dialog were considered, the employment effects of feedstock use were evaluated and finally, the innovation, knowledge and education potential were estimated. Table 4 lists the values given for the indicators. In addition, results are illustrated in Fig. 2 as a spider diagram.

Processing costs of lignocellulosics are higher due the more complicated structure of the biomass and more demanding sugar extraction. Therefore, the feedstock cost of corn is the highest [63]. In contrast to crop biomasses, cultivation, harvesting and transportation costs are not formed during the usage of industrial by-products.

Biodiversity and land use impacts are negative when using crops that need to be cultivated, and more severe for edible crops. Because industrial by-products would be formed even without their utilization in biobutanol production, they are assumed to have no impact on biodiversity and land use. Hazardous and toxic material usage is the highest in corn production, because of fertilizer and pesticide usage. Water is required the most in crop biomass cultivation. Water is required also in hydrolysis of lignocellulosics, while the whey permeate pretreatment is not water intensive. Non-edible crop biomass consumes the most energy compared to other feedstocks. This is primarily due to transportation. The energy and water demand for the hydrolysis of lignocellulosics (straw and sawdust) is similar.

Table 4. Sustainability indicator values

\begin{tabular}{lcccc}
\hline & Corn & Straw & $\begin{array}{c}\text { Whey } \\
\text { permeate }\end{array}$ & Sawdust \\
\hline Economic indicators & & & & \\
\hline Feedstock price & -2 & -1 & 0 & 0 \\
Processing costs & -1 & -2 & -1 & -1.5 \\
Value added & 0.5 & 2 & 1 & 1.5 \\
\hline Environmental indicators & & & & \\
\hline Water consumption & -2 & -1 & 0 & -0.5 \\
Hazardous and toxic material usage & -2 & -1 & 0 & -1.5 \\
Biodiversity and land use & -2 & -1 & 0 & 0 \\
Wastes vs. by-products & 1.5 & -0.5 & -1 & 1 \\
Energy & -1 & -2 & -0.5 & 0 \\
\hline Social indicators & & & & \\
\hline Ethicality and competing demand & -2 & 0 & -0.5 & 0 \\
Customer acceptance and social dialog & -2 & 0.5 & 1 & 1 \\
Employment effects & 0.5 & 2 & 1 & 1 \\
Innovation and education potential & 0 & 2 & 1 & 2 \\
\hline
\end{tabular}




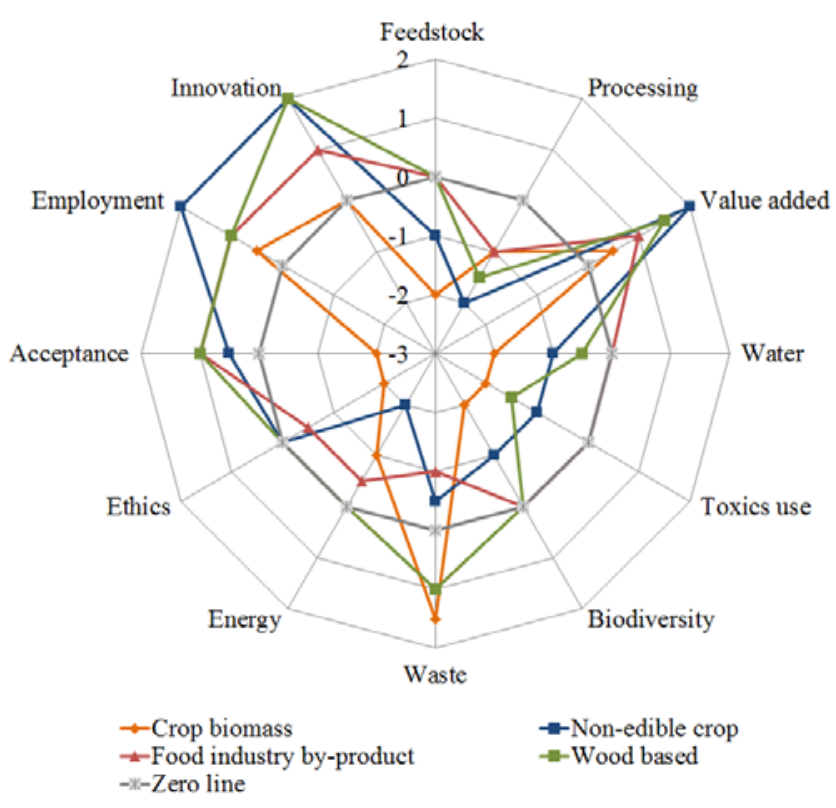

Figure 2. Sustainability assessment of selected feedstocks for biobutanol production

Biodiversity and land use impacts are negative when using crops that need to be cultivated, and more severe for edible crops. Because industrial by-products would be formed even without their utilization in biobutanol production, they are assumed to have no impact on biodiversity and land use. Hazardous and toxic material usage is the highest in corn production, because of fertilizer and pesticide usage. Water is required the most in crop biomass cultivation. Water is required also in hydrolysis of lignocellulosics, while the whey permeate pretreatment is not water intensive. Non-edible crop biomass consumes the most energy comparing with other feedstocks. This is primarily due to transportation. The energy and water demand for the hydrolysis of lignocellulosics (straw and sawdust) is similar. However, since the sawdust-based process is in symbiosis with a pulp and paper mill, the plant's residual steam can be utilized. Considering that the by-product of corn processing is valuable, a positive value is given. Since the starch content of corn is high, the yield of the biobutanol is high as well. However, pretreatment requites sulphuric acid, and use of process residue is not possible without neutralization.

Ethically, the use of non-edible crop or wood-based biomass is the most acceptable as the competing use of these feedstocks is minimal compared to edible crops and food industry by-products. Customer acceptance and social dialog are especially positive in Finland in terms of wood-based feedstocks. Employment effects are the most positive for agricultural by-products, as they require more resources for collection and pretreatment. Employment effects are positive also to corn as it is a widely used raw material, but it is assumed that it is not going to create a lot of new jobs in the near future. The innovation and education potential is the highest for lignocellulosics, as it is currently under intense study. Table 5 summarizes the main benefits and key negative impacts of assessed feedstocks.

Based on this assessment, it can be concluded that the highest positive sustainability impact is that of wood-based feedstock, with non-edible agricultural crops being second best. The challenge of both feedstocks is in the processing technology. However, these challenges can be overcome through research, which will further improve innovation and knowledge potential. The key challenge of any food-based feedstock is competing demand, even in case of food industry by-products. Another significant challenge is the need for arable land and water for cultivation which, in some countries, can be a challenge even in case of non-food crops. In Finland, both wood-based feedstock and non-food crops can be 
viable, yet the consumer acceptability and social dialogue supporting the use of wood-based feedstock is somewhat higher. The higher employment potential of agricultural biomass will raise its feedstock cost, and also increase the value added. Overall, in Finland, the highest potential is in integrating lignocellulosic-based biofuel technology with for example pulp\& paper plants, which can take advantage of the supply chain of the industrial plant, utilize by-products and waste heat in symbiosis and thus contribute to the lowest combined environmental impacts with the highest collective social benefits.

Table 5. Summary of sustainability impacts of selected feedstocks

\begin{tabular}{|c|c|c|}
\hline Feedstock & Benefits driving sustainability & Challenges to sustainability \\
\hline Crop biomass (corn) & $\begin{array}{l}\text { - Processing wastes are of } \\
\text { value } \\
\text { - Minor impacts to } \\
\text { employment and value } \\
\text { added }\end{array}$ & $\begin{array}{l}\text { - Competing demand for food } \\
\text { creates ethical challenges } \\
\text { - Consumer acceptance low } \\
\text { - High demand for water and } \\
\text { arable land } \\
\text { - High cost of feedstock and } \\
\text { toxics use in pre-processing } \\
\text { - No significant innovation } \\
\text { potential }\end{array}$ \\
\hline Non-edible crops & $\begin{array}{l}\text { - Highest employment and } \\
\text { innovation potential } \\
\text { - Highest value added } \\
\text { - No ethical conflicts, } \\
\text { consumer acceptability } \\
\text { mostly positive }\end{array}$ & $\begin{array}{l}\text { - High processing costs and } \\
\text { energy demand } \\
\text { - Water intensive } \\
\text { pre-processing using toxics }\end{array}$ \\
\hline (whey) & $\begin{array}{l}\text { - Innovation and employment } \\
\text { potential } \\
\text { - Positive value added } \\
\text { - High consumer acceptability } \\
\text { - Relatively low energy and } \\
\text { water demand in processing } \\
\text { - No toxics used }\end{array}$ & $\begin{array}{l}\text { - Costly processing } \\
\text { - Lowest product-to-waste ratio } \\
\text { - Potential competing demand }\end{array}$ \\
\hline Wood-based (sawdust) & $\begin{array}{l}\text { - High innovation potential } \\
\text { and value added } \\
\text { - Positive employment } \\
\text { impacts } \\
\text { - Highest consumer } \\
\text { acceptability } \\
\text { - By-product of marketable } \\
\text { value }\end{array}$ & $\begin{array}{l}\text { - Highest pre-processing costs } \\
\text { - Toxics used in pre-processing }\end{array}$ \\
\hline
\end{tabular}

\section{Challenges in assuring sustainability of biofuels}

The first challenge in the process and product evaluation is defining system boundaries, the accurate description of all process steps and selecting relevant and measurable indicators for the evaluation. In many cases, it is demanding to find sufficient and reliable information on all process steps and, thereby, some assumptions or simplifications are required. The production processes for biofuels as well as their direct and indirect environmental and social impacts are very complex and, if evaluation is not based on the same definitions and boundaries for the process, the evaluations are not comparable. 
When a sustainability assessment is done in a research and design phase, the target is to drive innovation for sustainability. This would require decision-support tools for the sustainability innovation process. With such tools, it would be possible to affect the environmental performance at the early design phase. It would, undoubtedly, provide a competitive advantage to the company if the consumption of energy, material, and water, as well as the emissions to air and water and waste releases of new products and processes would be known in advance. To gain information on all the above mentioned indicators is very important in the phase of adjusting the value-chain management. In the case of process development of biofuel production, legislative requirements such as the RED Directive will also have to be taken into consideration. It has been pointed out that the RED methodology excludes many critical issues such as indirect land use impacts and does not adequately consider allocation problems and uncertainty of individual parameters [90]. Evidently, there is a need to define common criteria for sustainability for biofuels. It is expected that the standards defined by technical committee of CEN/TC 383 will provide a solution to this problem and it would offer tools to be used also in the early design phase.

Meanwhile, mandatory blending targets, tax exemptions and subsidies have been set to increase the production and use of biofuels, although the EC is regulating the use of tax exemptions and incentives in Member States in order to avoid overcompensation. Increased oil prices will probably make production and use of biofuels more attractive in the future, but it is yet unclear how much and for how long a time will government support be needed before the biofuel economy can become profitable for industry and consumers. [2]

\section{CONCLUSIONS}

Both environmental and political pressures require increased biofuel production in the future. When choosing biofuels for the transportation sector, sustainability aspects in both the production processes and in the use of biofuels need to be taken into account. In addition, it is important to ensure that the evaluation base for sustainability, including emission calculations, is comparable and relevant.

In this article, biobutanol has been discussed as a potential future transportation biofuel. The advantage of biobutanol is its superior environmental and fuel properties, when compared to more commonly used biofuels such as ethanol. The economic competitiveness of biobutanol production depends on many aspects such as feedstock cost, product yield in fermentation including the separation and purification steps of biobutanol and the recovery of by-products. The process can be enhanced e.g. by exploiting the potential of low-cost feedstocks, using modified bacterium strains to gain better product yields and by finding more energy-efficient processing techniques. Use of raw materials classified as wastes or by-products, as well as utilization of all process outputs is also vital. The challenge with the waste material usage is in its heterogeneous nature. The research to increase the efficiency of the fermentation process should take this challenge into account. Also the yield of butanol should be increased dramatically, to ensure the capability of up-scaling the process to industrial scale. Apart from resource efficiency, sustainable process design also considers the economic, environmental and social impacts caused by the upstream and downstream processes.

There are many ongoing attempts (such as BioGrace, The Roundtable on Sustainable Biofuels, and development of calculation tools such as GREET) for measuring and reporting the sustainability aspects of the biofuel value chain. Most of them focus on controlling land use impacts and GHG emissions. There is still a demand for defining common criteria, definitions and assessment principles for evaluating sustainability. Finally, in order to have comparable results of sustainability assessment, the indicators and evaluation methods should be clearly stated and harmonized. These indicators should 
highlight and include the value of biofuels from waste products and take into account the avoidance of land-use change and emissions. In this paper sustainability assessment included selection of most important environmental, economic and social indicators. These were used to compare certain feedstocks for biobutanol production. Whilst corn is the most used feedstock for biofuel processing, it seems that other feedstocks have several advantages in perspective of numerous social and environmental aspects. Our assessment concluded that, in a Finnish perspective, the highest potential for sustainably is if biobutanol production was integrated into pulp \& paper mills for example. Whilst in a European context even non-food feedstocks and agricultural by-products have their own challenges, due to the vast natural resources of Finland, the use of non-food crops could be a viable alternative. A key element pointed out was that, when evaluating sustainability, the assessment cannot consider the manufacturing process in isolation from the surrounding society. Employment effects and regional value-added impacts provide strong consumer acceptance and will further contribute to the increase of social capital.

\section{ACKNOWLEDGEMENTS}

The Academy of Finland (project no. 124510, New, innovative sustainable transportation fuels for mobile applications: from biocomponents to flexible liquid fuels), The Doctoral Program in Energy Efficiency and Systems, and The Finnish Funding Agency for Technology and Innovation (research project no: 1428/31/2009, Intensification of bioprocess chains) are acknowledged for the financial support of this work.

\section{REFERENCES}

1. Directive 2009/28/EC of the European parliament and the council on the promotion of the use of energy from renewable sources and amending and subsequently repealing Directives 2001/77/EC and 2003/30/EC, 23.4.2009, 2009.

2. Sorda, G., Banse, M., Kemfert, C., An overview of biofuel policies across the world, Energy Policy, Vol. 38, pp 6977-6988, 2010.

(http://dx.doi.org/10.1016/j.enpol.2010.06.066)

3. Burridge, E., Chemical profile: N-butanol:

http://www.icis.com/Articles/2009/03/09/9198054/chemical-profile-n-butanol.html [Accessed Jan 31, 2013], 2009. (http://dx.doi.org/10.1002/ bit.22003 PMid: 18727018)

4. Lee, S.Y., Park, J.H., Jang, S.H., Nielsen, L.K., Kim, J., Jung, K.S., Fermentative butanol production by clostridia, Biotechnol. Bioeng., Vol. 101, pp 209-228, 2008.

5. Gabriel, C.L., Butanol fermentation process, Ind Eng Chem, Vol 20, pp 1063-1067, 1928. (http://dx.doi.org/10.1021/ie50226a020)

6. García, V., Päkkilä, J., Ojamo, H., Muurinen, E., Keiski, R.L., Challenges in biobutanol production: How to improve the efficiency?, Renew. Sust. Energy Rev., Vol.15, pp 964-980, 2011. (http://dx.doi.org/10.1016/j.rser.2010.11.008)

7. Cascone, R., Biobutanol - a replacement for bioethanol?, Chem. Eng. Prog., Vol. 104, pp S4-S9, 2008.

8. Wu, M., Wang, M., Liu, J., Huo, H., Life-cycle assessment of corn-based butanol as a potential transportation fuel. Report of Energy Systems Division, Argonne National Laboratory: http://www.transportation.anl.gov/pdfs/AF/448.pdf, 2007.

9. Butamax ${ }^{\mathrm{TM}}$ Advanced Biofuels, Biobutanol. A more advanced biofuel: http://www.butamax.com/_assets/pdf/biobutanol_a_more_advanced_biofuel.pdf, 2009. 
10. Niemistö, J., Saavalainen, P., Isomäki, R., Kolli, T., Huuhtanen, M., Keiski, R.L., Biobutanol production from biomass. In: Gupta, V. K., Tuohy, M.G. (Eds.), Biofuel Technologies-Recent Developments, Springer-Verlag, Berlin-Heidelberg, pp 443-470, 2013. (http://dx.doi.org/10.1007/978-3-642-34519-7_17)

11. Kumar, M., Gayen, K., Developments in biobutanol production: New insights, Appl. Energy, Vol. 88, pp 1999-2012, 2011. (http://dx.doi.org/10.1016/j. apenergy.2010.12.055)

12. Ezeji, T., Milne, C., Price, N.D., Blaschek, H.P., Achievements and perspectives to overcome the poor solvent resistance in acetone and butanol-producing microorganisms, Appl. Microbiol. Biotechnol., Vol. 85, pp 1697-1712, 2010. (http://dx.doi.org/10.1007/s00253-009-2390-0 PMid:20033401 )

13. Ni, Y., Sun, Z., Recent progress on industrial fermentative production of acetone-butanol-ethanol by Clostridium acetobutylicum in China, Vol. 83, pp 415-423, 2009. (PMid: 19430776)

14. Qureshi, N., Blaschek, H.P., Economics of butanol fermentation using hyper-butanol producing Clostridium beijerinckii BA101, Food. Bioprod. Process., Vol. 78, pp 139-144, 2000. (http://dx.doi.org/10.1205/096030800532888)

15. Qureshi, N., Blaschek, H.P., Butanol production from agricultural biomass, In: Shetty, K., Pometto, A., Paliyath, G., Levin, R.E., (Eds.), Food Biotechnology, Boca Raton, FL: CRC Press (Taylor\&Francis), pp 525-551, 2005.

16. Groot, W.J., Van der Lans, R.G.J.M., Luyben, K.C.A.M., Technologies for butanol recovery integrated with fermentations, Process Biochem., Vol. 27, pp 61-75, 1992. (http://dx.doi.org/10.1016/0032-9592(92)80012-R)

17. Soni, B.K., Das, K., Ghose, T.K., Bioconversion of agro-wastes into acetone butanol, Biotechnol. Lett., Vol. 4, pp 19-22,1982. (http://dx.doi.org/10.1007/BF00139276)

18. Parekh, S.R., Parekh, R.S., Wayman, M., Ethanol and butanol production by fermentation of enzymatically saccharified $\mathrm{SO}_{2}$-prehydrolysed lignocellulosics, Enzyme Microb. Tech., Vol. 10, pp 660-668. 1988. (http://dx.doi.org/10.1016/0141-0229(88)90057-9)

19. Qureshi, N., Li, X.-L., Hughes, S., Saha, B.C., Cotta, M.A., Butanol production from corn fiber xylan using Clostridium acetobutylicum, Biotechnol. Progr., Vol. 22, pp 673-680, 2006. (http://dx.doi.org/10.1021/bp050360w PMid: 16739948)

20. Qureshi, N., Ezeji, T.C., Ebener, J., Dien, B.S., Cotta, M.A., Blaschek, H.P., Butanol production by Clostridium beijerinckii. Part I: Use of acid and enzyme hydrolyzed corn fiber, Bioresource Technol., Vol. 99, pp 5915-5922, 2008. (http:// dx. doi.org/10.1016/j. biortech.2007.09.087 PMid: 18061440)

21. Marchal, R., Ropars, M., Pourquié, J., Fayolle, F., Vandecasteele, J.P., Large-scale enzymatic hydrolysis of agricultural lignocellulosic biomass. Part 2: Conversion into acetone-butanol, Bioresource Technol., Vol. 42, pp 205-217, 1992.

(http://dx.doi. org/10.1016/0960-8524(92)90024-R)

22. Qureshi, N., Saha, B.C., Dien, B., Hector, R.E., Cotta, M.A., Production of butanol (a biofuel) from agricultural residues: Part I - Use of barley straw hydrolysate, Biomass Bioenerg., Vol. 34, pp 559-565, 2010. (http://dx.doi.org/10.1016/j.biombioe. 2009.12.024)

23. Marchal, R., Rebeller, M., Vandecasteele, J.P., Direct bioconversion of alkali-pretreated straw using simultaneous enzymatic hydrolysis and acetone butanol production, Biotechnol. Lett., Vol. 6, pp 523-528, 1984.

(http://dx.doi.org/10.1007/BF00139996) 
24. Qureshi, N., Saha, B.C., Hector, R.E., Hughes, S.R., Cotta, M.A., Butanol production from wheat straw by simultaneous saccharification and fermentation using Clostridium beijerinckii: Part I -Batch fermentation, Biomass Bioenerg., Vol. 32, pp 168-175, 2008. (http://dx. doi.org/10.1016/j. biombioe.2007.07.004)

25. Qureshi, N., Saha, B.C., Cotta, M.A., Butanol production from wheat straw by simultaneous saccharification and fermentation using Clostridium beijerinckii: Part II - fed-batch fermentation, Biomass Bioenerg., Vol. 32, pp 176-183, 2008. (http://dx.doi.org/10.1016/j.biombioe.2007.07.005)

26. Thang, V.H., Kanda, K., Kobayashi, G., Production of Acetone-Butanol-Ethanol (ABE) in Direct Fermentation of Cassava by Clostridium saccharoperbutylacetonicum N1-4, Appl. Biochem. Biotech., Vol. 161, pp 157-170, 2010. (http://dx. doi.org/10.1007/s12010-009-8770-1 PMid: 19771401)

27. Campos, E.J., Qureshi, N., Blaschek, H.P., Production of acetone butanol ethanol from degermed corn using Clostridium beijerinckii BA101, Appl. Biochem. Biotech., Vol. 98-100, pp 553-561, 2002. (http:// dx. doi.org/10.1385/ABAB: 98-100: 1-9: 553)

28. Ezeji, T., Qureshi, N., Blaschek, H.P., Production of acetone-butanol-ethanol (ABE) in a continuous flow bioreactor using degermed corn and Clostridium beijerinckii, Process Biochem., Vol. 42, pp 34-39, 2007. (http://dx.doi.org/10.1016/j.procbio.2006.07.020)

29. Qureshi, N., Saha, B.C., Hector, R.E., Dien, B., Hughes, S., Liu, S., Iten, L., Bowman, M.J., Sarath, G., Cotta, M.A., Production of butanol (a biofuel) from agricultural residues: Part II - Use of corn stover and switchgrass hydrolysates, Biomass Bioenerg., Vol. 34, pp 566-571, 2010.

(http://dx.doi.org/10.1016/j.biombioe.2009.12.023)

30. Marchal, R., Blanchet, D., Vandecasteele J.P., Industrial optimization of acetone-butanol fermentation: a study of the utilization of Jerusalem artichokes, Appl. Microbiol. Biotechnol., Vol. 23, pp 92-98, 1985.

(http://dx.doi.org/10.1007/BF00938959)

31. Saddler, J.N., Yu, E.K.C., Mes-Hartree, M., Levitin, N., Brownell, H.H., Utilization of enzymatically hydrolyzed wood hemicelluloses by microorganisms for production of liquid fuels, Appl. Environ. Microb., Vol. 45, pp 153-160, 1983. (PMid: 16346161 PMCid:242246)

32. Yu, E.K.C., Deschatelets, L., Saddler, J.N., The Bioconversion of wood hydrolyzates to butanol and butanediol, Biotechnol. Lett., Vol. 6, pp 327-332, 1984. (http://dx.doi.org/10.1007/BF00129064)

33. Sjolander, N.O., Langlykke, A.F., Peterson, W.H., Butyl alcohol fermentation of wood sugar, Ind. Eng. Chem., Vol. 30, pp 1251-1255,1938. (http://dx.doi.org/10.1021/ie50347a011)

34. Maddox, I.S., Murray, A.E., Production of n-butanol by fermentation of wood hydrolysate, Biotechnol. Lett., Vol. 5, pp 175-178, 1983. (http://dx.doi.org/10.1007/BF00131898)

35. Voget, C.E., Mignone, C.F., Ertola, R.J., Butanol production from apple pomace, Biotechnol. Lett., Vol. 7, pp. 43-46, 1985. (http://dx. doi.org/10.1007/BF01032418)

36. Ennis, B.M., Maddox, I.S., Production of solvents (ABE Fermentation) from whey permeate by continuous fermentation in a membrane bioreactor. Bioprocess Eng., Vol. 4, pp 27-34, 1989. (http://dx. doi.org/10.1007/BF00612667)

37. Maddox, I.S., Qureshi, N., Gutierrez, N.A., (1993) Utilization of Whey by Clostridia and Process Technology, In: Woods, D.R., (Ed.), The Clostridia and Biotechnology, pp 343-369. Butterworth-Heinemann, Oxford, 1993. 
38. Qureshi, N., Maddox, I.S., Reduction in butanol inhibition by perstraction: Utilization of concentrated lactose/whey permeate by Clostridium acetobutylicum to enhance butanol fermentation economics, Food Bioprod. Process., Vol. 83, pp 43-52, 2005. (http://dx.doi.org/10.1205/fbp. 04163)

39. Schoutens, G.H., Nieuwenhuizen, M.C.H., Kossen, N.W.F., Butanol from whey ultrafiltrate: batch experiments with Clostridium beyerinckii LMD 27.6, Appl. Microbiol. $\quad$ Biotechnol., $\quad$ Vol. 19, pp 203-206, 1984. (http://dx.doi.org/10.1007/BF00251837)

40. Welsh, F.W., Veliky, I.A., Production of acetone-butanol from acid whey, Biotechnol. Lett., Vol. 6, pp 61-64, 1984. (http://dx.doi.org/10.1007/BF00128231)

41. Ezeji, T., Blaschek, H.P., Fermentation of dried distillers' grains and solubles (DDGS) hydrolysates to solvents and value-added products by solventogenic clostridia, Bioresource Technol., Vol. 99, pp 5232-5242, 2008. (http://dx. doi.org/10.1016/j. biortech.2007.09.032 PMid: 17967532)

42. Badr, H.R., Toledo, R., Hamdy, M.K., Continous acetone-ethanol-butanol fermentation by immobilized cells of Clostridium acetobutylicum, Biomass Bioenerg., Vol. 20, pp 119-132, 2001. (http://dx.doi.org/10.1016/S0961-9534(00)00068-4)

43. Grobben, N.C., Eggink, G., Cuperus, F.P., Huizing, H.J., Production of acetone, butanol and ethanol (ABE) from potato wastes; fermentation with integrated membrane extraction, Appl. Microbiol. Biotechnol., Vol. 39, pp 494-498, 1993. (http://dx.doi.org/10.1007/BF00205039)

44. Gutierrez, N.A., Maddox, I. S., Schuster, K.C., Swoboda, H., Gapes, J. R., Strain comparison and medium preparation for the acetone-butanol-ethanol (ABE) fermentation process using a substrate of potato, Bioresource Technol., Vol. 66, pp 263-265, 1998. (http://dx. doi.org/10.1016/S0960-8524(98)00051-0)

45. Nimcevic, D., Schuster, M., Gapes, J.R., Solvent production by Clostridium beijerinckii NRRL B592 growing on different potato media, Appl. Microbiol. Biotechnol., Vol. 50, pp 426-428, 1998. (http://dx.doi.org/10.1007/s002530051315 PMid: 9830093)

46. Lee, J., Seo, E., Kweon, D.-H., Park, K., Jin, Y.-S., Fermentation of rice bran and defatted rice bran for butanol production using Clostridium beijerinckii NCIMB 8052, J. Microbiol. Biotech., Vol. 19, pp 482-490, 2009.

(http:// dx. doi.org/10.4014/jmb.0804.275 PMid: 19494696)

47. Al-Shorgani, N.K.N., Kalil, M.S., Yussof, W.M.W., Biobutanol production from rice bran and de-oiled rice bran by Clostridium saccharoperbutylacetonicum N1-4, Bioprocess Biosyst. Eng., Vol. 35, pp 817-826, 2012. (http://dx. doi.org/10.1007/s00449-011-0664-2 PMid:22147105)

48. Qureshi, N., Lolas, A., Blaschek, H.P., Soy molasses as fermentation substrate for production of butanol using Clostridium beijerinckii BA101, J. Ind. Microbiol. Biot., Vol. 26, pp 290-295, 2001. (http://dx.doi.org/10.1038/sj.jim. 7000131 PMid: 11494105)

49. Wiley, A.J., Johnson, M.J., McCoy, E., Peterson, W.H., Acetone-butyl alcohol fermentation of waste sulfite liquor, Ind. Eng. Chem., Vol. 33, pp 606-610, 1941. (http://dx.doi.org/10.1021/ie50377a013)

50. Liu, Z., Ying, Y., Li, F., Ma, C., Xu, P., Butanol production by Clostridium beijerinckii ATCC 55025 from wheat bran, J. Ind. Microbiol. Biot., Vol. 37, pp 495-501, 2010. (http://dx. doi.org/10.1007/s10295-010-0695-8 PMid: 20393827) 
51. Murty, M.V.S., Chandra, T.S., Fermentability of hemicelluloses extracted from municipal waste and commercial xylans by Clostridium sp, Appl. Microbiol. Biotechnol., Vol. 47, pp 212-217, 1997. (http://dx.doi.org/10.1007/s002530050915)

52. Claassen, P.A.M., Budde, M.A.W., López-Contreras, A.M., Acetone, butanol and ethanol production from domestic organic waste by solventogenic clostridia, J. Mol. Microbiol. Biotechnol., Vol. 2, pp 39-44, 2000. (PMid: 10937486)

53. López-Contreras, A.M., Claassen, P.A.M., Mooibrock, H., De Vos, W.M., Utilisation of saccharides in extruded domestic organic waste by Clostridium acetobutylicum ATCC 824 for production of acetone, butanol and ethanol, Appl. Microbiol. Biotechnol., Vol. 54, pp 162-167, 2000. (http://dx.doi.org/10.1007/s002530000374 PMid: 10968627)

54. Jesse, T.W., Ezeji, T.C., Qureshi, N., Blaschek, H.P., Production of butanol from starch-based waste packing peanuts and agricultural waste. J. Ind. Microbiol. Biotechnol., Vol. 29, pp 117-123, 2002. (http://dx.doi.org/10.1038/sj.jim.7000285 PMid: 12242632)

55. Kobayashi, G., Eto, K., Tashiro, Y., Okubo, K., Sonomoto, K., Ishizaki, A., Utilization of excess sludge by Acetone-Butanol-Ethanol fermentation employing Clostridium saccharoperbutylacetonicum N1-4 (ATCC 13564), J. Biosci. Bioeng., Vol. 99, pp 517-519, 2005. (http://dx. doi.org/10.1263/jbb.99.517 PMid: 16233826)

56. BioGrace project, The renewable energy directive - information page: http://www.biograce.net/content/biofuelrelatedpolicies/renewable\%20energy\%20dire ctive, [Accessed Feb 8, 2013], 2011.

57. Europa press release, Commission sets up system for certifying sustainable biofuels, Memo IP/10/711: http://europa.eu/rapid/pressReleasesAction.do?reference=IP/10/711 [Accessed Feb 8, 2013], 2010.

58. CEN - European Committee for Standardization, Sustainably produced biomass for energy applications - Standards under development: http://www.cen.eu/cen/Sectors/TechnicalCommitteesWorkshops/CENTechnicalCom mittees/Pages/default.aspx?param=648007\&title=Sustainably\%20produced\%20biom ass\%20for\%20energy\%20applications [Accessed Feb 18, 2013].

59. International Organization for Standardization, Sustainability criteria for bioenergy: http://www.iso.org/iso/home/store/catalogue_ics/catalogue_detail_ics.htm?ics1=13\&i cs2=20\&ics3=99\&csnumber=52528 [Accessed Feb 18, 2013].

60. Lenz, T.G., Morelra, A.R., Economic evaluation of the Acetone-Butanol Fermentation, Ind. Eng. Chem. Prod. Res. Dev., Vol. 19, pp 478-483, 1980. (http://dx.doi.org/10.1021/i360076a002)

61. Gapes, J.R., The economics of acetone-butanol-ethanol fermentation: Theoretical and market considerations, J. Mol. Microbiol. Biotechnol. Vol. 2, pp 27-32, 2000. (PMid: 10937484)

62. Pfromm, P.H., Amanor-Boadu, V., Nelson, R., Vadlani, P., Madl, R., Bio-butanol vs. bio-ethanol: A technical and economic assessment for corn and switchgrass fermented by yeast or Clostridium acetobutylicum, Biomass Bioen., Vol. 34, pp 515-524, 2010. (http://dx. doi.org/10.1016/j. biombioe.2009.12.017)

63. Kumar, M., Gouyal, Y., Sarkar, A., Gayen, K., Comparative economic assessment of ABE fermentation based on cellulosic and non-cellulosic feedstocks, Appl. Energ., Vol. 93, pp 193-204, 2012. (http://dx. doi.org/10.1016/j.apenergy.2011.12.079)

64. Ramey, D., Yang, S.-T., Final report, Production of butyric acid and butanol from biomass: www.afdc.energy.gov/pdfs/843183.pdf, 2004.

65. Ethanol Producer Magazine, Industry reacts to BP, DuPont butanol announcement. Ethanol Producer Magazine: 
http://www.ethanolproducer.com/articles/2274/industry-reacts-to-bp-dupont-butano l-announcement, September 2006 [Accessed Apr 9, 2013].

66. Marlatt, J.A., Datta, R., Acetone-butanol fermentation process development and economic evaluation, Biotechnol. Prog., Vol. 2, pp 23-28, 1986. (http://dx.doi.org/10.1002/btpr.5420020106 PMid: 20568182)

67. Dadgar, A., Foutch, G., Improving the acetone-butanol fermentation process with liquid-liquid extraction, Biotechnol. Prog., Vol. 4, pp 36-39, 1988. (http://dx.doi.org/10.1002/btpr.5420040107)

68. Liu, J., Fan, L.T., Seib, P., Friedler, F., Bertok, B., Downstream process synthesis for biochemical production of butanol, ethanol, and acetone from grains: generation of optimal and near-optimal flowsheets with conventional operating units, Biotechnol. Prog., Vol. 20, 1518-1527, 2004. (http://dx.doi.org/10.1021/bp049845v PMid: 15458338)

69. Liu, J., Fan, L.T., Seib, P., Friedler, F., Bertok, B., Holistic approach to process retrofitting: application to downstream process for biochemical production of organics, Ind. Eng. Chem. Res., Vol. 45, pp 4200-4207, 2006.

(http://dx.doi.org/10.1021/ie051014m)

70. Qureshi, N., Hughes, S., Maddox, I.S., Cotta, M.A., Energy-efficient recovery of butanol from fermentation broth by adsorption, Bioprocess Biosyst. Eng., Vol. 27, pp 215-222, 2005. (http://dx.doi.org/10.1007/s00449-005-0402-8 PMid: 15744503)

71. Qureshi, N., Blaschek, H.P., Recent advances in ABE fermentation: hyper-butanol producing Clostridium beijerinckii BA101, J. Ind. Microbiol. Biot., Vol. 27, pp 287-291, 2001. (http://dx.doi.org/10.1038/sj.jim. 7000114 PMid: 11781803)

72. Niemistö, J., Kujawski, W., Keiski, R.L., Pervaporation performance of composite poly(dimethyl siloxane) membrane for butanol recovery from model solutions. $J$. Membr. Sci., 2013.(http://dx. doi.org/10.1016/j. memsci.2013.01.047)

73. Van der Merwe, A.B., Cheng, H., Görgens, J.F., Knoetze, J.H., Comparison of energy efficiency and economics of process designs for biobutanol production form sugarcane molasses, Fuel, Vol. 105, pp 451-458., 2013.

(http://dx.doi.org/10.1016/j.fuel.2012.06.058)

74. Natural Resources Canada, The Addition of Bio-Butanol to GHGenius and a Review of the GHG Emissions from Diesel Engines With Urea SCR, NRC Report, prepared by $(\mathrm{S} \& \mathrm{~T})^{2}$ Consultants, BC, Canada:

http://www.ghgenius.ca/reports/ButanolGHGenius.pdf [Accessed Feb 5, 2013], 2007.

75. Argonne National Laboratory, GREET Model, http://greet.es.anl.gov/ [Accessed Feb 12, 2013], 2012.

76. Wu, M., Wang, M., Liu, J., Huo, H., Assessment of potential life-cycle energy and greenhouse gas emission effects from using corn-based butanol as a transportation fuel, Biotechnol. Prog., Vol. 24, pp 1204-1214, 2008. (http://dx.doi.org/10.1002/btpr.71 PMid: 19194933)

77. Swana, J., Yang, Y., Behnam, M., Thompson, R., An analysis of net energy production and feedstock availability for biobutanol and bioethanol, Bioresour. Technol., Vol, 102, pp 2112-2117, 2011. (http://dx.doi.org/10.1016/j. biortech.2010.08.051 PMid:20843683)

78. BioGrace project, Publishable final report, http://www.biograce.net/app/webroot/files/file/BioGrace_-_Final_publishable_report.p df, 2012.

79. The Roundtable on Sustainable Biofuels, http://buiprojekte.f2.htw-berlin.de:1339/ [Accessed Jan 31, 2013], 2011. 
80. Huesemann, M.H., The failure of eco-efficiency to guarantee sustainability: Future challenges for industrial ecology, Environ. Prog., Vol. 23, pp 264-270, 2004. (http://dx.doi.org/10.1002/ep.10044)

81. Manley, J.B., Anastas, P.T., Cue, B.W., Frontiers in Green Chemistry: meeting the grand challenges for sustainability in R\&D and manufacturing, J. Clean. Prod., Vol. 16, pp 743-750, 2008. (http://dx.doi.org/10.1016/j.jclepro.2007.02.025)

82. Demirbas, A., Political, economic and environmental impacts of biofuels: A review, Appl. Energy, Vol. 86, pp S108-S117, 2009. (http://dx.doi.org/10.1016/j.apenergy.2009.04.036)

83. Heck, P., Regionale Wertschöpfung als Zielvorgabe einer dauerhaft nachhaltigen, effizienten Wirtschaftsförderung, Forum für angewandtes systemisches Stoffstrommanagement, Jahrgang 2, p. 5-12, 2004.

84. Hoffmann, D., Creation of regional added value by regional bioenergy resources, Renew. Sust. Energy Rev., Vol. 13, pp. 2419-2429, 2009. (http://dx.doi.org/10.1016/j.rser.2009.04.001)

85. Searchinger, T., Heimlich, R., Houghton, R.A., Dong, F., Elobeid, A., Fabiosa, J., Tokgoz, S., Hayes, D., Yu, T.H., Land-use change greenhouse gases through emissions from use of U.S. croplands for biofuels increases, Science, Vol. 319, pp 1238-1240, 2008. (http://dx.doi.org/10.1126/science.1151861 PMid: 18258860)

86. Kendall, A., Chang, B., Estimating life cycle greenhouse gas emissions from corn-ethanol: a critical review of current U.S. practices, J. Clean. Prod., Vol. 17, pp 1175-1182, 2009. (http://dx.doi.org/10.1016/j.jclepro. 2009.03.003)

87. Börjesson, P., Tufvesson, L.M., Agricultural crop-based biofuels - resource efficiency and environmental performance including direct land use changes, J. Clean. Prod., Vol. 17, pp 1175-1182, 2011.

88. Abbasi, T., Abbasi, S.A., Biomass energy and the environmental impacts associated with its production and utilization, Renew. Sust. Energy Rev., Vol. 14, pp 919-937, 2010. (http://dx. doi.org/10.1016/j.rser.2009.11.006)

89. Saavalainen, P., Pongrácz, E., Keiski R.L., Sustainability assessment of chemical processes: Evaluation of five synthesis routes of DMC, Manuscript.

90. Soimakallio, S., Koponen, K., How to ensure greenhouse gas emission reductions by increasing the use of biofuels? - Suitability of the European Union sustainability criteria, Biomass Bioenerg., Vol. 35, pp 3504-3513, 2011.

(http://dx.doi.org/10.1016/j.biombioe.2011.04.041) 